\title{
Managing Cultural Diversity: Implication for Organizational Innovativeness
}

\author{
Amakiri Don-Solomon and Perewari Fakidouma
}

\section{ABSTRACT}

\begin{abstract}
It is a known fact that the workplace is a repository of culturally diverse workforce, who brings their difference cultural inclinations and expertise to bear in pursuit of the general organizational goal. A diverse workforce comes with both benefits and challenges which are consequences of how the workforce is managed. This paper examines the theoretical implication of cultural diversity management on organizational innovativeness. The piece began with conceptual exposition of culture and the organization, organizational innovativeness as well as cultural diversity. Further, the paper identified cultural variables in the impeding workforce with subsequent management efforts of the diversity. Eventually, diverse cultural implications on organization innovativeness were emphasized. Findings are that; team that has variety of diverse characteristics can collectively spark a height of inventiveness, and likely exude better capacity to resolve intricate glitches and offers superior solution. Also, organization thrives creatively and innovatively in a culturally diverse workforce tolerant environment.
\end{abstract}

Keywords: cultural diversity, organizational culture, organizational innovativeness.

\author{
Submitted : August 03, 2021 \\ Published : August 29, 2021 \\ ISSN: $2507-1076$ \\ DOI: $10.24018 / \mathrm{ejbmr} .2021 .6 .4 .1031$ \\ Amakiri Don-Solomon* \\ Department of Office \& Information \\ Management, Niger Delta University, \\ Bayelsa State, Nigeria \\ (e-mail: donamaco52@gmail.com) \\ Perewari Fakidouma \\ Office of the secretary of Vice- \\ Chancelor, University of Africa, Toru- \\ Orua, Bayelsa State, Nigeria. \\ (e-mail: perefakidouma@gmail.com)
}

*Corresponding Author

\section{INTRODUCTION}

The dynamics of enterprise operations in a highly unpredictable macro-environment always prompt organizations to become innovative as a coping strategy to remain competitive and relevant in business, this however would be a mirage without the human elements that bring to bear their expertise and efforts to keep the wheel of the organization running. Understanding the diversity in cultural inclination of these human resources coexisting in an organization left one wonder if their diversity is a strength or weakness to the organization, milieu to its innovativeness drive. Well, proffering answer to this question predicates the focus of this paper; which is tilted towards theoretically investigating the implication of managing cultural diversity in the workplace on organizational innovativeness.

[1] in line with this prelude avers that firms are progressively in dare need of their employees' creativity to deliver innovative products with superior value in the global marketplace.

Earlier investigation has shown that team diversity promotes creativity and innovativeness [2].

Thus, asserting that team's cultural diversity is an option for coping with the challenges that comes with organizational innovativeness.

\section{Culture And the Organization}

[3] posits culture as similar minds creating a niche that set apart adherents of one cluster from another. Supportively, [4], avers culture as diverse ideals and actions that frontiers success. [5], further perceive culture as justly conventional general dogmas, behaviors, and morals of a given society. From the above positions one can conclude that culture is the lifestyle of a people overly, which can be expressed in their language, dresses, foods, marriage rights and conducts in social gatherings.

The concept of culture is now implied in organizational context because organization exist as a rift of the society hence, have its underlying philosophies, believes, values that directs the behaviors of its members. Therefore, organizational culture is the organization's prospect, experiences, philosophy, as well as the values that funnel members behavior, which are expressed in member's selfimage, working patterns, and interactions with the public. Culture of the organization is rooted in shared attitudes, beliefs, customs, written and unwritten rules that are put in place over time (The business dictionary). Additively, [6], noted perceive culture in the organization parlance as a form of shared conventions that premise organizational practices, it stipulates apposite behavior for various situations. [7] states that culture in the above light forms operands of human relations at the individual, groups and even with possible clients and investors as well as pointer to employee's identity with their organization. More so, [8], stated that organization's dogmas have a severe impinge on all organization actors. [9] assert that the ideas of a culture should be shared in the organization for compliance, understanding that every employee comes from inherently diverse cultures. 


\section{ORGANIZATIONAL INNOVATIVENESS}

Organizational innovativeness also called administrative or management Innovativeness [10], insinuates "how managers do what they do" [11]:4. The innovative touch of an organization is expressed in the unusual ideas put forward in recruitment process, resources management, tasks structuring, reward system, marketing strategies and production processes [12].

Innovativeness has multidimensional approach displaying subjective and objective traits, which [13] conceptualized as procedural and structural innovativeness. The success of an organizational innovativeness depends subjectively on how raw materials such as innovation and strategic thought process of persons and groups are harnessed for the objective structures of innovation.

[14] are of the view that an organization being innovative is a direct effect of strategic initiatives proactively concerted by decision maker as a response to external environmental changes. Implication of organizational innovativeness therefore is an overhaul consistent modification and improvement of all organizational operations to remain competitive.

\section{IV.CULTURAL DIVERSITY EXPOSITION}

Cultural diversity portrays the distinct features of a particular social system that distinguish group associations of cultural significance [15]. According to [16] cultural diversity considering organizational setting is referred to the likely and variances among staffs' demographics; age, sex, cultural upbringing, corporeal abilities and debilities, ethnicity, and religion orientation. Workplace cultural diversity is a blend of labor force from dissimilar socio-cultural experiences working in an organization [17]. Complementarily, [18] revealed it is the social consortium characteristics which exposes the degree of objectives or subjective variances existing among groups coexisting in an organization. [16] further states that diversity makes the workforce heterogeneous, and this comes with its merits and demerits.

In a nutshell, cultural diversity in the organizational setting is all about the distinct cultural features that brandish organizational changes or similarity to one another; the blend of employees from several races, backgrounds, religious beliefs and so on [19].

\section{Cultural Variables}

A whole lot of characteristics come to play when talking about cultural variables; they are the culturally heterogeneous variables or elements that characterize the organization. These variables are inherent in employees who bring them to the work place which the organizational culture must reshape.

Geographical regions, language differences, caste, religion, perceptional difference and attitude amongst others were cultural variable model enunciated to explain diversity in the workplace [16]. Further, [16] posits that organizations that employ efficient workforce regardless of these diverse cultural variables can remain competitive at the marketplace.

[20] conceptualized cultural diversities in three dimensional levels as shown below:
TABLE I: CULTURAL DIVERSITY DIMENSIONS

\begin{tabular}{|c|c|c|}
\hline Primary Dimension & $\begin{array}{c}\text { Secondary } \\
\text { Dimensions }\end{array}$ & Tertiary Dimensions \\
\hline $\begin{array}{c}\text { - Race } \\
\text { - Ethnicity } \\
\text { - Gender } \\
\text { - Age } \\
\text { - Disability }\end{array}$ & $\begin{array}{c}\text { - Religion } \\
\cdot \text { Culture } \\
\text { - Sexual orientation } \\
\text { - Thinking style } \\
\text { - Geographic origin } \\
\text { - Family status } \\
\text { - Lifestyle } \\
\text { - Economic status } \\
\text { - Political orientation } \\
\text { - Work experience } \\
\text { - Education } \\
\text { - Language } \\
\text { - Nationality }\end{array}$ & $\begin{array}{c}\text { - Beliefs } \\
\text { - Assumptions } \\
\text { - Perceptions } \\
\text { - Attitudes } \\
\text { - Feelings } \\
\text { - Values } \\
\text { - Group norms }\end{array}$ \\
\hline
\end{tabular}

The table sculpts different dimensions that entwine to turn out unique syntheses of human culturally diverse variables that interact and impact each other, and are displayed in peculiar organizational context.

Conversely, [21] revealed Hofstede's dimensional cultural variables typology to include power distance, masculinity/femininity, individualism/collectivism and uncertainty avoidance. These dimensions reflect the behavior and attitudinal differences of individuals in the workplace [22]. [23] noted that national culture which Hofstede's study was premised on is the underpinning of cultural diversity and understanding the differences is perceived as a competitive advantage. According to [24], long-term orientation versus short-term orientation and indulgence are captured as dimensions fifth and sixth in his earlier works.

\section{MANAGING CUlTURAL DiVERSITY}

Managing culturally diverse work force suitably is organizational strength for competitive advantage; employees from different cultures contribute with different viewpoints, skills, and concerns [20]. Managing culturally diverse workforce effectively implies that the workforce can carry out their work at its full potential in organization without discrimination among themselves [25].

Effective management of a culturally diverse workforce has many benefits than one can imagine including being healthier in serving a diverse external client base, display multiple perspectives and clarifications in handling intricate issues because they seem to better understand the legal, political, social, economic and cultural requirements [16].

[15] underpin that multiracial organizations have an edge in appealing and retaining the best talent. Firms that appeal to and retain qualified members and uphold organizational justice in career advancement treatments, gain competitive edge and derive high quality human resources dividends.

On the contrary culturally diverse work group has its setbacks especially under situations of hesitation and intricacy which may lead to frustration; unanimous derive to a given course of action may be a bane in a culturally diverse workgroup and can result in adverse culturally riffed organizational conflicts [15]. 


\section{CULTURAL DIVERSITY IMPLICATION ON ORGANIZATIONAL INNOVATIVENESS}

The impact of cultural diversity on organizational innovativeness relatively has two-pronged effect. This has been issues of concern in management and economics literatures. Positive effects of diversity can be felt in areas of increased synergies arising from the association of different viewpoints, and increased opportunities for knowledge recombination. Conversely, common negative impact is in the aspect of communication and problems resulting from conflict resolution [13].

[26] asserts that diversity in multiethnic workforce is linked with constructive outcomes which improves originality, inventiveness and problem solving. Further commenting [26] said team that has variety of diverse characteristics individuals, can collectively spark a height of inventiveness and novelty, which exudes strength to deal with complex snags and proffer superior solutions. Succinctly articulating these positions was [27] cited in [15] that creativity thrives on a diverse workforce which is the bedrock of organization innovativeness.

Moreso, [28] investigation found advanced levels of innovation in firms with higher cultural diversity tolerant region than regions with lower levels of diversity. [29], corroboratively opined that flexibility, creativity, and innovativeness are fast tracked with the unlike minds, implication is that like-minds makes one-sided decisions which limits the diameter of innovative and creative thoughts.

[30] noted that diversity can aid more sound decisionmaking and problem-solving prowess with diverse, robust expertise, and more vigorous critical appraisal of perspectives.

\section{CONCLUSION}

This paper examined the theoretical implications of cultural diversity management on organizational innovativeness. Concerted efforts were made with recourse to this purpose by reviewing prior literatures on culture and the organization with further underpinning of organizational innovativeness conceptual expositions. The paper discussed scholarly issues surrounding cultural diversity sequel to cultural variables where the paper asserts language differences, religion, perceptional/attitudinal differences, ethnicity and regional differences inclusion of Hofstede's cultural dimensional variables of power distance, femininity/masculinity, short/long-term orientation, indulgence, individualism/collectivism and uncertainty avoidance as cultural variables observable in the workplace. After deciphering possible management efforts of these cultural differences and its implication on the organizational innovativeness the paper draw its findings and conclusion amongst others that; first, culturally diverse workforce is organizational strength for coping with the competitive business landscape; second, organization thrives creatively and innovatively in a culturally diverse workforce tolerant environment; third, flexibility, creativity, and innovativeness are fast tracked within workforce with unlike mind sets.

\section{REFERENCES}

[1] R Bouncken, Cultural diversity in entrepreneurial teams: findings of new ventures in Germany. Creativity and Innovation Management, 2009, 13(4), 240-53.

[2] T. Y., Craig, and J. R. Kelly, Group cohesiveness and creative performance. Group dynamics: Theory, Research, and Practice, 1999, 3(4), 243-256.

[3] G. Hofstede, Culture's consequences. Beverly Hills, Ca.: Sage publishers, 1980

[4] E. Schein, Organizational culture. American psychologist, 1990.

[5] J.P. Kotter, and J.L. Heskett, Corporate culture and performance. Free press, New York, 1992.

[6] D. Ravasi, and M. Schultz, "Responding to organizational identity threats: exploring the role of organizational culture". Academy of management journal, 2006, 49 (3), 433-458.

[7] P. Schrodt, "The relationship between organizational identification and organizational culture: employee perceptions of culture and identification in a retail sales organization". Communication studies, 2002, 53, 189-202.

[8] D. Strewart, Growing the Corporate Culture, 2010. Retrieved from https://www.wachovia.com/foundation/v/index.jsp?vgnextoid=ab411f 07760aa110VgnV CM1 000004b0d1872.

[9] S. Fakhar, A. L, Rana. S., Lalarukh and R. K. Ayesha, Impact of Organizational Culture on Organizational Performance: An Overview. Interdisciplinary journal of contemporary research in business, 2012, (3) $9,975-985$

[10] F. Damanpour, "Footnotes to research on management innovation", Organization Studies, 2014, 35(9), 1265-1285, available at: https://doi.org/10.1177/0170840614539312

[11] G. Hamel, "The why, what, and how of management innovation". Harvard business review, 2006, 84(2),72-84.

[12] F. R. A. Marlon V. R. G., Simone and D. Silvio, Literature on organizational innovation: past and future. Innovation \& management review, 2016, 15(1), 2-19.

[13] O. Muge and E. Erkan, Cultural diversity, knowledge diversity and innovation. European commission research area, 2013.

[14] A. Subramanian and S. Nilakanta, Organization innovativeness; exploring the relationship between organization determinant of innovation, types of innovation and measures of organizational performance. Omega international journal of management sciences, 1996, 24(6), 631-647.

[15] I. A. Donatus, Cultural diversity: implications for workplace management. Journal of diversity management, 2007, 2(4), 1-6.

[16] S. Ankita, Workforce diversity: a key to improve productivity. Procedia economics and finance, 2014 , (11)1, 76-85

[17] O. Henry and A. J Evans, Critical review of literature on workforce diversity. African journal of business management, 2007, 072-076

[18] R. Gupta, Workforce diversity and organizational performance. International journal of business and management invention, 2013, 2(6), 36-41.

[19] K. O, John, O.K.J Babatunde. and C.N. Justice, Workforce diversity and employees' performance: evidence from a Nigerian bank. Journal of economic behavior, 2019, 9(1), 3-16.

[20] M. Barbara, Cultural diversity in organizational theory and practice. Journal of intercultural management, 2010, 2(2), 5-15

[21] S. Eriksson and C. Hagg, Cultural diversity: how to manage a crosscultural workforce in a global organization- a study between India and Sweden, 2016.

[22] G. Hofstede, Culture's consequences: comparing values, behaviors, institutions and organizations across nations, Beverly Hills, Ca.: Sage publishers, 2001

[23] D. R. Molnar, Serving the World: a cross-cultural study of national culture dimensions and servant leadership. Proquest dissertations publishing, 2007.

[24] G., Hofstede, G. J., Hofstede and M. Minkov, Cultures and organizations: software of the mind, revised and expanded. New York: McGraw-Hill USA, 2010.

[25] C. Torres, and M. Bruxelles, Capitalizing on global diversity. HR Magazine, 1992, 37(12), 30.

[26] N. Adler, International dimensions of organizational behavior. The international Executive, 2002, 28(1).

[27] G. Morgan, Endangered species: new ideas. Business month, 1989, 133(4), 75-77.

[28] A. Niebuhr, Migration and innovation does cultural diversity matter for regional activity? IAB discussion paper. 2006. Available: http://doku.iab.de/discussionpapers/2006/dp1406.pdf.

[29] M.F. Ozbilgin and T. Ahu, Global diversity management: an evidencebased approach., Basingstoke, New York, Palgrave Macmillan Houndmills, 2008. 
[30] N. Bassett-Jones, The paradox of diversity management, creativity and innovation. Creativity and innovation management, 2005, 14(2), 165179.

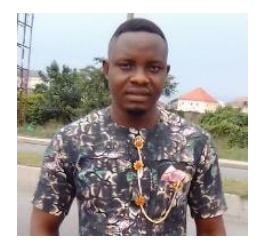

Don-Solomon Amakiri $\mathrm{PhD}$ hails from Akakumama community in Nembe LGA of Bayelsa State, Nigeria. He was born in 17th Dec. 1987. He holds B.sc degree in Office Management Technology in Niger Delta University 2010. M.sc in Management from University of Port-Harcourt 2015 and a terminal $\mathrm{PhD}$ Degree in Management with specialty in Organizational Behavior in Niger Delta University 2021. He currently lectures in the Department of Office and Information Management, Faculty of Management Sciences, Niger Delta University Wilberforce Island, Bayelsa. He has authored 17 articles in peer reviewed local and international journals, 2 books - Christian literatures and anchored several online facilitation and programs. He is a motivator, infopreneur, teacher, prolific writer, researcher and Christian, married to Selina with two kids.

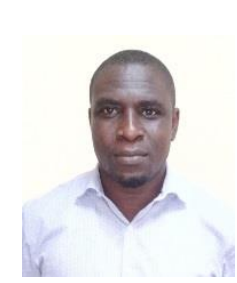

Perewari Fakidouma hails from AgbobiriOkordia in Yenagoa Local Government Area of Bayelsa State, Nigeria. Born on the $18^{\text {th }}$ of June 1981 at his home town, Agbobiri-Okordia. Holds Master of Science (MSc) degree in Management from University of Port Harcourt, -2015, Post Graduate Degree (PGD) in Accountancy from University of Port Harcourt, -2011 and Bachelor of Science (B.sc) Business Education with specialization in Accountancy from Rivers State University of Science and Technology-2006 (now River State University). All in Rivers State, Nigeria.

$\mathrm{He}$ is a non-teaching staff in the Registry Department of a fledging University (University of Africa, Toru-Orua), Sgbama Local Government Area, Bayelsa State of Nigeria, West-Africa from 2018 till date- as Administrative Officer. He has worked in both public and private organizations and has held political offices. 2013-2018 (Accountant I)Federal Roads Maintenance Agency (FERMA), 2007-2010 (Accounts Clerk and NUCCEFW UNION REPRESENTATIVE)-SAIPEM CONTRACTING NIG. LTD. Political Offices; 2013-2015- Deputy Chief-of-Staff to the Mayor, Yenagoa Municipal Council and 2011-2012 (Secretary to SSA to the Governor of Bayelsa State. He is interested in acquiring more knowledge in research writing and his areas of research interest include; Human Resource Management, Organizational Behaviour, and Entrepreneurship Management.

Mr. Fkidouma has had training and courses/workshop in Trade Unionism, Public Service, and Professional University Administration among others His hobbies are; singing, travelling, reading and swimming. He is happily married with children. 